\title{
Workplace spirituality: A tool or a trend?
}

\begin{tabular}{|c|c|}
\hline \multicolumn{2}{|c|}{$\begin{array}{l}\text { Author: } \\
\text { Philip J.W. Schutte }\end{array}$} \\
\hline \multicolumn{2}{|c|}{ 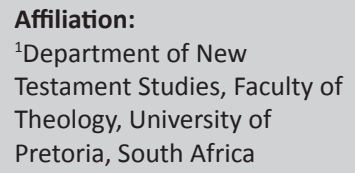 } \\
\hline \multicolumn{2}{|c|}{$\begin{array}{l}\text { Project leader: A.G. van Aarde } \\
\text { Project number: } 2334682\end{array}$} \\
\hline \multicolumn{2}{|c|}{$\begin{array}{l}\text { Description: } \\
\text { Prof. Dr Schutte is } \\
\text { participating in the research } \\
\text { project, 'Biblical Theology } \\
\text { and Hermeneutics', directed } \\
\text { by Prof. Dr Andries G. van } \\
\text { Aarde, Post Retirement } \\
\text { Professor, Department of } \\
\text { New Testament Studies, } \\
\text { Faculty of Theology, } \\
\text { University of Pretoria }\end{array}$} \\
\hline \multicolumn{2}{|c|}{$\begin{array}{l}\text { Corresponding author: } \\
\text { Flip Schutte, } \\
\text { pjwschutte@telkomsa.net }\end{array}$} \\
\hline \multicolumn{2}{|c|}{$\begin{array}{l}\text { Received: } 17 \text { Dec. } 2015 \\
\text { Accepted: } 17 \text { Mar. } 2016 \\
\text { Published: } 19 \text { Aug. } 2016\end{array}$} \\
\hline \multicolumn{2}{|c|}{$\begin{array}{l}\text { How to cite this article: } \\
\text { Schutte, P.J.W., 2016, } \\
\text { 'Workplace spirituality: A tool } \\
\text { or a trend?', HTS Teologiese } \\
\text { Studies/Theological Studies } \\
\text { 72(4), a3294. http://dx.doi. } \\
\text { org/10.4102/hts.v72i4.3294 }\end{array}$} \\
\hline \multicolumn{2}{|c|}{$\begin{array}{l}\text { Copyright: } \\
\text { (c) 2016. The Authors. } \\
\text { Licensee: AOSIS. This } \\
\text { is licensed under the } \\
\text { Creative Commons } \\
\text { Attribution License. }\end{array}$} \\
\hline \multicolumn{2}{|l|}{ Read online: } \\
\hline 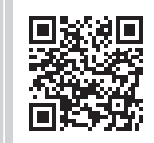 & $\begin{array}{l}\text { Scan this QR } \\
\text { code with your } \\
\text { smart phone or } \\
\text { mobile device } \\
\text { to read online. }\end{array}$ \\
\hline
\end{tabular}

Workplace spirituality is a construct widely discussed over the past few decades and it is a much-disputed inquiry field which is gaining the interest of practitioners and scholars. Some clarifications regarding concepts and definitions are necessary in order to structure and direct the current debate. The aim of this conceptual article is to gain a better understanding regarding the direction in which this field of study is progressing and to put the question on the table namely, whether workplace spirituality is only a new tool to be used in leadership development or is it a trend to be taken seriously? The results showed that this field has potential to further development. This article can be used as foundation for future studies within the knowledge area of practical theology.

\section{Introduction}

Globally increasing changes in the labour landscape have led to increasing demands for employers and employees facing the challenges of the 21st century. These changes also led to redefining the essence of work. The working individual spends more time at work than at home (Albertini \& Smith 2008:10), with the consequence that people bring more and more their whole selves to work rather than just their body and brains (Naidoo 2014:1). They now also bring their soul and their spirit to work, which led to a growing interest in the phenomenon called: workplace spirituality.

Workplace spirituality is a construct widely discussed over the past few decades and it is gaining the interest of practitioners and scholars (Dreyer \& Hermans 2014:3; Benefiel, Fry \& Geigle 2014:175; Gotsis \& Kortezi 2008:575; Hayden \& Barbuto 2011:142). In 2005, there were already 30 business schools who offered spirituality for future leaders as part of their MBA programs (Phipps 2012:177).

Spirituality as phenomenon in theology and religious studies gained popularity in the 1950s and 1960s (Fourie 2014:3).The discovery of a spiritual dimension of work can be traced back to the late 1980s (Gotsis \& Kortezi 2008:575) during the second wave of interest in spirituality which came with the movement towards self-improvement. Since the beginning of the 1990s, the interest in spirituality has shown a mushroom movement (Fourie 2014:3).

The growth of interest in this phenomenon is also due to the relevance of subjective factors in organisational settings, such as an individual quest for higher purpose, personal meaning and transcendent values (Gotsis \& Kortezi 2008:576). Some argue that the interest in workplace spirituality has emerged to ease tumultuous social and business changes, increased work insecurity and the profound change in values globally (Dreyer \& Hermans 2014:3). There also seems to be a general increase of interest in spirituality as a phenomenon and a whole spiritual renaissance as an emerging paradigm (Benefiel, Fry \& Geigle 2014:175).

In today's politically correct environment, organisations are understandably wary of opening discussions and meaningful dialogues about spirituality because of the potential to offend (Van Tonder \& Ramdass 2009:1). This wariness of spirituality may also be due to the fact that spirituality has often been understood as no different than religiosity. Therefore, in order to address spirituality in the workplace, it is critical to understand that spirituality and religiosity need not be viewed or treated as synonymous. Spirituality has to do with universal human experiences, whereas religion has to do with the articulation and perhaps propagation of a particular ideology (Hayden \& Barbuto 2011:142). Because employees spend an increasing amount of time at work, they have actively pursued opportunities for meaningful experiences in the workplace (Benefiel, Fry \& Geigle 2014:175).

One of the greatest challenges facing leaders today is the need to develop new business models that accentuate leadership, employee well-being, sustainability and social responsibility without sacrificing profitability, revenue growth and other indicators of financial performance. It is all about the so-called triple bottom line, namely people, planet and profit (Benefiel, Fry \& Geigle 2014:176). 
Spirituality in the workplace is a much-disputed inquiry field. Thus, some clarifications are regarded as necessary in order to carry on with this discussion (Gotsis \& Kortezi 2008:578). The aim of this article is to contribute to the debate by getting more clarification regarding the definitions and the concepts so that this field of study can position itself within academia. The article also wants to put the question on the table namely if workplace spirituality is only a new tool to be used in leadership development or is it a trend to be taken seriously?

\section{Towards a definition}

The terms spirituality and religion have different but overlapping meanings in both academic and popular use. According to Phipps (2012:179), spirituality refers to a common human condition, while religion refers to the polity, practices and creeds of a particular denomination or faith body. Spirituality can be a unifying force in the field of leadership, while religion can be fractious.

According to Mitroff and Denton (1999:9) who did an empirical study on spirituality in the workplace, their respondents answered that one can have a negative view of religion but a positive view of spirituality. It is possible to be spiritual without believing in or affirming a higher power. Religion is organised, close-minded and intolerant whereas spirituality is extremely individualised, open-minded, tolerant and universal. It is accessible to all people, no matter what their particular beliefs.

\section{Spirituality}

The term 'spirituality' resists a precise definition (Fourie 2014:2). There are nearly as many definitions of spirituality as there are people who write about the topic (Hoffman 2007:189). It refers, according to Mitroff and Denton (1999:1), to the basic feeling of being connected with one's complete self, others, and the entire universe. It is a highly individual and intensely personal awareness. You do not have to be religious in order to be spiritual. Spirituality is connected to the idea that everything and everyone have a purpose. Van Dierendonck and Mohan (2006:234) add to this the inner aspects of a person that produce an individualised awareness of one's inner self and a sense of being part of a deeper spiritual dimension, directly related to the sacred, not restricted to religious participation or to adherence to a certain denomination. Dreyer and Hermans (2014:3) summarise the notion of spirituality as a search for - and a means of reaching - something beyond human existence, creating a sense of connectedness with the world and with the unifying source of all life. It is thus an expression of people's profound need for coherent meaning, love and happiness. The need to create meaning is inherent for our very existence as human beings.

\section{Workplace}

'Workplace' is according to Hicks (2003:168) conceived as a fair system of cooperative relations, within which employees holding different worldviews should be treated as free and equal. Work is an integral part of adult identity and may have an influence on every other area of adult life; it is a source of status and identity, self-esteem, social recognition, expression of personal interests and capabilities, and it presents opportunities to experience meaningfulness in life (Fourie 2014:2).

One of the fundamental problems with the workplace revolves around the alienation and resultant loss of meaning by individuals in the workplace. The workplace has become a space where work-related activities are being performed without a sense of meaning (Steenkamp \& Basson 2013:3).

\section{Workplace Spirituality}

A universally acceptable definition for the combination of these concepts, namely 'spirituality in the workplace' does not exist (Gotsis \& Kortezi 2008:577; Van Tonder \& Randass 2009:2). It is a complex and multi-faceted construct. Some scholars use the term 'a meaningful workplace' instead of the concept 'spirituality in the workplace' (Steenkamp \& Basson 2013:1). They view spirituality in the workplace as one of the factors that contribute to a meaningful workplace (Steenkamp \& Basson 2013:6).

There is not a dominant paradigm or a prevailing framework within which the discussion on workplace spirituality is carried out. Consequently, the current discourse is often discontinuous, in some instances unsystematic, and it is mainly constituted of sporadic and spermatic theoretical contributions. The fact that there is not a widely accepted definition of workplace spirituality can to some extent be accountable for this phenomenon, because the existence of an agreed-on definition provides the minimum prerequisite for the development of a broadly accepted framework for theoretical discourse and empirical examination (Gotsis \& Kortezi 2008:579). The following definitions can however be listed:

Giacalone and Jurkiewicz (2003:13) offer as definition: 'Workplace spirituality is a framework of organisational values evidenced in the culture that promotes employees' experience of transcendence through the work process, facilitating their sense of being connected to others in a way that provided feelings of completeness and joy'.

Dunchon and Plowman (2005:809) define workplace spirituality in terms of its components namely a recognition that employees have an inner life; an assumption that employees desire to find work meaningful; and a commitment by the company to serve as a context or community for spiritual growth.

Gotsisand and Kortezi (2008:579) have the following definition: '...workplace spirituality is an experience of transcendence, interconnectedness, personal completeness and joy, analysed in different theoretical frameworks'. 
Phipps (2012:179) defines spirituality as the human desire for connection with the transcendent, the desire for integration of the self into a meaningful whole, and the realisation of one's potential.

According to the above cited definitions on workplace spirituality a definition will thus at least contain the concepts of meaningfulness, completeness and joy, connectedness, and the experience of transcendence. This is in line with Hoffman's (2007:189) remark that the idea of making work meaningful and integrating work with the rest of life is found repeatedly in the different studies and approaches on spirituality in the workplace.

\section{The theological roots of workplace spirituality}

In the 6th century St. Benedict wrote his rules for a monastic life, emphasising the integration of work and prayer. The two complimented each other and work was just as holy to Benedict as prayer because both provided discipline for body and soul and served a good end (Fry \& Geigle 2014:176). Life according to St. Benedict must have time for labour, time for listening and time for contemplation (Hoffman 2007:201).

During the Reformation, Martin Luther reaffirmed the holiness of ordinary, daily work. He claimed that all people should seek perfection in their work to attain holiness through the discipline of working faithfully (Fry \& Geigle 2014:176). His writings were influenced by the broader social context in which the agrarian feudal economies of late medieval Europe were beginning to be challenged by the growth of more entrepreneurial urban economies (Dawson 2005:223). Luther argued that a divine calling or vocation could be followed no matter what one's occupation was. Non-religious work or work outside the borders of the monastery was thus no longer a punishment but was, in Luther's thinking, a blessing and something sacred to be enjoyed (Dawson 2005:224).

The idea of daily work as something with a spiritual dimension or a divine vocation became a central tenet of the Protestant work ethic, which found its fullest expression in the works of Protestant theologians such as John Calvin and other writers in the Puritan tradition (Hardy 1990:65).

During the Industrial Revolution people were expected to employ compartmentalisation, that is, to leave their feelings, emotions, discretion, curiosity and creativity at the office's door (Ashar \& Lane-Maher 2004:251). Protestants developed a work ethic during this period that aimed to spiritualise the workplace. Through the concept of a 'calling, the Protestant work ethic held people responsible for doing their best in a quest for perfection' (Fry \& Geigle 2014:176).

The antecedents of today's emphasis on spirituality in the workplace reach back to the late 19th century in Europe and the United States. The Faith at Work movement arose during this period in response to a perceived lack of interest on the part of the Church towards lay people's experience in the secular workplace (Fry \& Geigle 2014:176). During the mid20th century, focused groups such as the International Christian Leadership, Full Gospel Businessmen's fellowship, the Audenshaw Foundation, and the Coalition for Ministry in Daily Life, revitalised the Faith at Work spirit. The dawn of the postmodern era led to a quest for the integration of faith and work. No longer content to park their souls at the door, people sought to bring their whole selves, body, mind, heart, and soul, to work (Fry \& Geigle 2014:177). People must be treated holistically. It is the recognition of this multi-faceted aspect of the human spirit which is the underpinning of a spiritual workplace (Hayden \& Barbuto 2011:152).

According to Miller and Ewest (2013:32), research has shown that most students, workers, marketplace professionals, and leaders want to live a holistic life that integrates, among other things, faith and work, but have few resources to help them do that. The sense of transcendence, having a calling through one's work and the need for membership in the corporate culture, community and social connections provide the foundation for a theory of workplace spirituality (Naidoo 2014:2).

Within theology, research on workplace spirituality is conducted from a public practical-theological perspective. Public practical theology includes the study of the religious praxis in the community in order to establish a social paradigm within theology (Fourie 2014:6). Therefore, practical theology indeed wants to gain a deeper understanding of the human in all the facets of his or her life. Its purpose is to facilitate the experience of meaningfulness and sense so that people can answer their existential questions within the paradigm in which they are operating.

\section{A leadership development tool?}

Some study workplace spirituality, according to Gotsis and Kortezi (2008:580), from an instrumentalistic perspective. They analyse the benefits for an organisation to become a spiritual place. They then identify links between spirituality in the workplace and outcomes such as an increased commitment to organisational goals, increased honesty and trust, greater kindness and fairness, increased creativity, even increased profits and morale, higher levels of productivity and performance, reduced absenteeism, connectedness with the colleagues job satisfaction and intrinsic motivation. Other positive outcomes are commitment towards the organisation, job satisfaction, productivity, self-career management, reduced inter-role conflict, reduced frustration, organisational self-esteem, retention and ethical behaviour (Benefiel et al. 2014:180). The implementation of workplace spirituality could thus have, according to this opinion, had a positive impact on the workplace, which in turn may be conducive to beneficial outcomes for complex organisational settings (Fourie 2014:6). Naidoo (2014:6) confirms this viewpoint by stating that companies are finding that employees who act on their personal sense of workplace spirituality are more creative, self-directed, committed and desirable employees and are therefore highly sought after. 
Some scholars also approach the matter from a different angle. Organisations are a reflection of their top leaders, thus making the spirituality of top leaders highly relevant (Phipps 2012:177). According to Naidoo (2014:2), Fairholm in the 1990s was one of the first scholars to put the terms 'spiritual' and 'leadership' together to explain spirituality in the context of workplace leadership, and since then others have attempted to validate his model in order to move the field towards a theory of leadership.

Professor Andre Delbecq presented a pilot course in 'spirituality for business leadership' for MBA students and CEOs at the Santa Clara University in California during the last quarter of 1998. Participants encompassed diverse religious orientations namely Hindu, Jewish, Catholic, Protestant, Unitarian, Buddhist and agnostics. In his final report after the course he wrote that the need for such a course was greater than he could ever have anticipated. Spirituality as component for leadership development in the workplace is all about the desire for personal integration of all the sides of oneself in business leadership through deepening spirituality (Delbecq 2000:126).

Should spirituality be integrated into the workplace for instrumental ends or should spirituality be seen as a central organising principle for the workplace, or just as a way in which employees personally experience their growth in the workplace? Phipps (2012:182) cautions against the abuse of personal spirituality as a tool for increasing productivity by garnering a deeper commitment from employees. Organisations may attempt to manipulate or use the concept of spirituality at work as a tool to simply increase productivity (Gotsis \& Kortezi 2008:583).

\section{A postmodern trend?}

Spirituality in the workplace can also be seen as maybe just a postmodern trend. Because of the anonymity in neighbourhoods, the decline in churches and communities as places where a sense of connectedness and community can be experienced, the workplace has become a substitute for that type of community (Van Tonder \& Ramdass 2009:2). Organisations where people work are becoming their most significant community and sometimes even replace their family, friendship circles and social groups. People are spending more time at work and there are diffuse boundaries between work and personal lives (Albertini \& Smith 2008:10).

The growing interest in eastern philosophies and the fact that more and more people admit their non-religiosity more openly stimulates a swing towards spirituality away from religiosity. These factors contribute to diversity in the workplace (Van Tonder \& Ramdass 2009:2). Spirituality, together with some distinctive values such as ecological sustainability, globalism, women's issues, social conscience and self-actualisation, has been brought about by the paradigm shift towards postmodernity. With this also came the adaptation of a holistic approach to managing organisations and, in particular, for the incorporation of spirituality into the workplace (Ashar \& Lane-Maher 2004:250).
Douglas Hick (2003:167) brought the term 'respectful pluralism' to the debate. He uses this terminology to indicate the diversity of religions, philosophies and orientations in the workplace. According to him, spirituality is an integral part of human life. A person coming to work brings his or her 'whole person' to work. The self cannot be fragmented. Spirituality as an integral part of human nature cannot be left outside certain aspects of human life and activity such as work. Employment relations as such must be framed by the fundamental commitment to dignity and respect in a just society. Employees should not be treated as simply another input to the production process (2003:170). According to Hick (2003:171), workplace spirituality is founded on this basis, and not on the mere fact that it can deliver improved outcomes at the organisational level.

A postmodern approach uses a methodological strategy that aims at understanding conditions of possibility rather than describing cause-effect relationships (Steenkamp \& Basson 2013:4). This is where respectful pluralism differs from other models of workplace spirituality. It treats the construct of spirit in the workplace as an end in itself that results from an inner need of human nature and not as a means to an organisational end - most often organisational productivity.

In the current economy a company's competitive advantage resides in its human resources. The qualities, commitment, responsibility, creativity and energy of the employees determine a company's success (Ashar \& Lane-Maher 2004:251). These values are seen by many as spiritual values, and this makes spirituality in the workplace relevant and a focus area at the moment. Leaders who nurture this concept want some common behavioural components from the employees and want their sense of connectedness and purposeful work to manifest in their professional role in the service of the greater good for the company (Ashar \& LaneMaher 2004:253).

\section{Does it have a future?}

Spirituality in the workplace enjoys widespread interest. It represents a worldview in which the emphasis is that work should be meaningful and significant and that an employee wants to bring his or her whole self to the workplace (Fourie 2014:7).When workplace spirituality is studied from only one religious tradition's perspective there is an inherent flaw in the study because the concept is then deprived of its universalistic nature. Moreover, one religious tradition's perspective fails to capture the complexity and the conceptual richness of such a multi-faceted term (Gotsis et al. 2008:582).

It appears to be a grassroots movement, as more and more people entertain the notion that work can be meaningful and fulfilling. This trend will endure because it speaks to the deeper needs of the human heart and provides a promising remedy to declining job satisfaction (Naidoo 2014:7).

There is also a need for thorough scientific evidence in order to establish with scientific certainty a connection between 
workplace spirituality and positive outcomes both at the organisational and the individual level. Without scientific evidence any reported positive relation between a spiritually orientated workplace and organisational or employee benefits may remain just an unfounded assumption (Gotsis et al. 2008:583).

Although one may argue the extent to which workplace spirituality may currently be viewed as an emerging paradigm in the social sciences, there is no doubt that there are a number of theoretical and empirical issues that need to be addressed before this promise can be fulfilled (Benefiel et al. 2014:183).

\section{Conclusion}

The aim of this article was to contribute to the debate regarding workplace spirituality by getting more clarity regarding the definitions, concepts and trends within this field of study. The article also wanted to put the question on the table namely if workplace spirituality is only a new tool to be used in leadership development or is it a trend to be taken seriously?

The findings of the literature review showed that there is not an agreed-on definition of the term 'workplace spirituality'. There is also an apparent difficulty for measuring such an inadequately defined, multi-faceted and highly personal construct, for the researchers have not entirely agreed on a set of core dimensions of spiritual expression and orientation. The absence of a widely accepted definition leaves space for obscurity and vagueness in the inquiry of this field.

Workplace spirituality cannot be put forward or treated as the panacea to all organisational problems or as a universal cure to the ills of modern management (Gotsis et al. 2008:583). It is a definite trend and a phenomenon that business and practical must take seriously.

Recommendations for further research is to investigate the questions namely that if spirituality is ultimately about nonmaterialistic concerns, is it appropriate to focus on the material gains to be reaped by integrating spirituality into organisational life? Is not in this way spirituality divested of its deeper essence? Is it not merely treated as a means to attain organisational profit and not as an end in itself? Is not the real meaning of spirituality lost?

Should spirituality be used for instrumental ends at work? How can a social scientific approach to studying business and management be integrated with a philosophical or theological approach to studying spirituality?

The contribution of this article is to underline the statement that strategic leaders and employees at the workplace already have spiritual beliefs that influence their exercise of leadership and their day-to-day operations in the workplace. This fact must be acknowledged and accommodated. Practical theology and human resource management as two knowledge areas must do research and develop an industry-specific body of knowledge for workplace spirituality, and they must investigate the practical implementation of this phenomenon, and the future academic research regarding this phenomenon, within the workplace of the future.

\section{Acknowledgements Competing interests}

The author declares that he has no financial or personal relationships which may have inappropriately influenced him in writing this article.

\section{References}

Albertini, E.D. \& Smith, D.P.J., 2008, 'A spiritual audit of a retail branch of a South African bank', SA Tydskrif vir Menslikehulpbronbestuur 6(1), 10-21.

Ashar, H. \& Lane-Maher, M., 2004, 'Success and spirituality in the new business paradigm', Journal of Management Inquiry 31(3), 249-260. http://dx.doi. org $/ 10.1177 / 1056492604268218$

Benefiel, M., Fry, L.W. \& Giegle, D., 2014, 'Spirituality and religion in the workplace: History, theory, and research', Psychology of Religion and Spirituality 6(3), 175-187. http://dx.doi.org/10.1037/a0036597

Dawson, J., 2005, 'A history of vocation: Tracing a keyword of work, meaning, and moral purpose', Adult Education Quarterly 55(3), 220-231. http://dx.doi. org/10.1177/0741713605274606

Delbecq, A.L., 2000, 'Spirituality for business leadership', Journal of Management Inquiry 9(2), 117-128. http://dx.doi.org/10.1177/105649260092005

Dreyer, J.S. \& Hermans, C.A.M., 2014, 'Spiritual character traits and leadership in the school workplace: An exploration of the relationship between spirituality and school leadership in some private and religiously affiliated schools in South Africa', Koers - Bulletin for Christian Scholarship 79(2), Art. \#2136, 9 p. http://dx.doi. org/10.4102/koers.v79i2.2136

Dunchon, D. \& Plowman, D.A., 2005, 'Nurturing the spirit at work: Impact on work unit performance', The Leadership Quarterly 16, 807-833. http://dx.doi. org/10.1016/j.leaqua.2005.07.008

Fourie, M., 2014, 'Spirituality in the workplace: An introductory overview', In die Skriflig 48(1), Art. \#1769, 8 p. http://dx.doi.org/10.4102/ids.v48i1.1769

Giacalone, R.A. \& Jurkiewicz, C.L., 2003, 'Toward a science of workplace spirituality', in R.A. Giacalone \& C.L. Jurkiewicz (eds.), Handbook of workplace spirituality and organizational performance, pp. 3-28, M E Sharpe Armonk, New York.

Gotsis, G. \& Kortezi, Z., 2008, 'Philosophical foundations of workplace spirituality: A critical approach', Journal of Business Ethics 78, 575-600. http://dx.doi. org/10.1007/s10551-007-9369-5

Hardy, L., 1990, The fabric of this world: Inquiries into calling, career choice, and the design of human work, Eerdmans, Grand Rapids, MI.

Hayden, R.W. \& Barbuto, J.E., 2011, 'Expanding a framework for a non-ideological conceptualization of spirituality in the workplace', Journal of Behavioural and Applied Management 12, 142-155.

Hicks, D.A., 2003, Religion and the workplace pluralism, spirituality, leadership, Cambridge University Press, Cambridge.

Hoffman, M.F., 2007, 'Ora etLabora (Prayer and Work): Spirituality, communication and organizing in religious communities', Journal of Communication \& Religion 30(2), 187-212.

Miller, D.W. \& Ewest, T., 2013, 'The present state of workplace spirituality: A literature review considering context, theory, and measurement/assessment', Journal of Religious and Theological Information 12, 29-54. http://dx.doi.org/10.1080/1047 7845.2013 .800776

Mitroff, I.I. \& Denton, E.A., 1999, 'A study of spirituality in the workplace', MIT Sloan Management Review 40(4), 1-14.

Naidoo, M., 2014, 'The potential of spiritual leadership in workplace spirituality', Koers - Bulletin for Christian Scholarship 79(2), Art. \#2124, 8 p. http://dx.doi. org/10.4102/koers.v79i2.2124

Phipps, K.A., 2012, 'Spirituality and strategic leadership: The influence of spiritual beliefs on strategic decision making', Journal of Business Ethics 106, 177-189. http://dx.doi.org/10.1007/s10551-011-0988-5

Steenkamp, P.L. \& Basson, J.S., 2013, 'A meaningful workplace: Framework, space and context', HTS Teologiese Studies/Theological Studies 69(1), Art. \#1258, 9 p. http:// dx.doi.org/10.4102/hts.v69i1.1258

Van Dierendonck, D. \& Mohan, K., 2006, 'Some thoughts in spirituality and eudemonic well-being', Mental Health, Religion and Culture 9(3), 227-238. http://dx.doi. org/10.1080/13694670600615383

Van Tonder, C.L. \& Ramdass, P., 2009, 'A spirited workplace: Employee perspectives on the meaning of workplace spirituality', SA Journal of Human Resource Management/ SA Tydskrif vir menslikehulpbronbestuur 7(1), Art. \#207, 12 p. http://dx.doi.org/10.4102/sajhrm.v7i1.207 